\title{
LEARNING PHYSICS THROUGH THE COOPERATIVE MODEL OF THE TYPE OF TAI OBSERVED FROM METACOGNITIVE SKILLS AGAINST COGNITIVE LEARNING OUTCOMES
}

\author{
Muhammad Satriawan \\ STKIP Bima, Dept. of Phisycs Education, NTB-Indonesia \\ e-mail: awanawansatriawan@gmail.com
}

\begin{abstract}
This study aims to determine whether there is: (1) Difference between the learning outcomes of students who taught used the model of TAI type of cooperative learning with students who taught used conventional learning models. (2) Difference between the learning outcomes of students with high metacognitive skills and students who had low metacognitive skills. (3) Interaction between the models of learning with metacognitive skills of learning outcomes. The samples taken 2 classes from 5 classes of the first grade science class at senior high school 5 Mataram that amounted 177 students, which are divided into an experimental group and a control group, the first used of cooperative learning model of the type of TAI and the second group using the conventional model. Data is collected by the tests for cognitive learning outcomes and questionnaire for the metacognitive skills. This experimental study using 2 × 2 factorial design. Data were analyzed using analysis of variance technique (ANAVA) two-way with SPSS 20.0 for windows. The results analysis of data on a significant level of 0.05 shows that: (1) significant values of the used learning models to learning outcomes the results of 0.300 (2) the significant value of metacognitive skills of students to learning outcomes the results of 0.000 , (3) significant interaction of learning with the used of models metacognitive skills of 0.674 . Conclusion: (1) there was no difference between students cognitive learning outcomes using the model of cooperative learning type of TAI with the conventional learning models, (2) there were differences in learning outcomes between students with high metacognitive skills and metacognitive skills low, (3) there was no interaction between the use of learning models (cooperative type TAI and Conventional) with metacognitive skills (high and low) of the students cognitive learning outcomes.
\end{abstract}

Keywords: Learning Physics, Learning models TAI, Metacognitive skills and Cognitive learning outcomes.

\section{INTRODUCTION}

Learning physics is a process or activity subjects physics educators in teaching physics to the learners, that it contains the efforts of educators to create a situation of learning and service to the ability, potential, interests, talents, and needs of the students of physics are very diverse in order optimal interaction between educators with learners and between learners with learners and ultimately achieve success in learning. Learning success depends not only on students, but also the role of educator. Learners and educators should play an active role in learning. Educators are required to condition the class and choose the right model of learning that learners' learning outcomes can be improved. One alternative that can be used to achieve this is by implement cooperative learning model types TAI. In the cooperative learning model types TAI, students are placed in small groups to 
complete the task heterogeneous group that has been prepared by educators, followed by individual assistance to students who need it. This model can create effective learning interactions during the process of learning (Slavin, 2008).

Moises and Masamichi (2006) states that the study can be regarded as a process of interaction between man and his environment that may be tangible personal, facts, concepts and theories. This means that the interaction process is the process of internalization of something into a self-study and was active with the five senses which will then generate the process of socialization. In this socialization process that will bring forth an experience that will lead the process of change in a person.

An important aspect which can help the process of change in a person who is rarely considered in the process of learning that metacognitive aspects. Metacognition (metacognitive) means awareness and control of cognitive processes. Metacognitive skills related to the understanding of the concept of the material under study in which students who has demonstrated high metacognitive skills of understanding the concept that high anyway. Certainly metacognitive skills needed by learners who study the physics lesson. In physics learning problems always arise that need to be addressed. Generally the problem that arises is less capable learners master the concepts presented study results akedemik learners is very low. Hong research (1999) revealed that students who have a high metacognitive skills will certainly have a better understanding of the concept as well. Metacognitive skills that can assist learners in mastering the concepts in depth because the learners are able to control the learning process.

\section{THE PURPOSE AND CONTEXT OF THE RESEARCH}

Based on this introduction, the research done by the formulation of the problem: "(1) Is there a difference in learning outcomes between students who use cooperative learning model of TAI with learners who use conventional learning model? (2) Is there a difference in learning outcomes between students who have a high metacognitive skill and learners who have low metacognitive skills? (3) Is there any interaction between learning model with metacognitive skills to the learning outcomes? Thus the purpose of research are to know the: (1) difference in learning outcomes between students who use cooperative learning model of TAI with learners who use conventional learning model, (2) difference in learning outcomes between students who have a high metacognitive skills and learners who have low metacognitive skills, (3) interaction between learning model with metacognitive skills on learning outcomes. With the hypothesis: (1) there is a difference in learning outcomes between students who use cooperative learning model of TAI with learners who use conventional learning model, (2) there is a difference in learning outcomes between students who have a high metacognitive skills and learners who have low metacognitive skills, (3) there is an interaction between learning model with metacognitive skills on learning outcomes.

\section{Literature Review}

Learning physics gradually implemented the preliminary stage, the core activities, and stabilization activities. In a preliminary event to consider asking educators prerequisite knowledge to students about the knowledge required to support the implementation of learning at the time. Technical implementation there are several ways such as by asking the lesson material that will be discussed. In addition, motivation can be carried out by asking questions, telling stories, or by bringing interesting props related to the physics of matter to be discussed at that time. While the core activities 
can be carried out through demonstration, experiment or both conventional as well as cooperative learning (Wieman et al., 2005).

Patel et al. (1991) revealed that the conventional learning model is still widely used in the study. Conventional learning is characterized by the provision of information, followed by a question and answer session, giving the task by educators, execution of tasks by learners, until finally educators feel that what has been taught can be understood by learners. One way to use the conventional learning methods including expository method, lectures, discussion and demonstration or with the collaboration of the method. One model of cooperative learning is learning model Team Assisted Individualization (TAI). This model puts pressure on the social effects of cooperative learning and problem solving in a teaching program, for example in terms of learning difficulties learners individually and raises awareness about what is known and what is unknown Slavin (2008).

Metacognition is knowledge about cognition generally equal to the awareness and knowledge of one's self cognition. Because it can be said that metacognition is awareness of what is known and what is unknown. Medium metacognition strategies refer to the way to raise awareness about thinking and learning processes that apply so that when consciousness is realized, it will arise where a person metacognitive skills can escort her mind by designing, monitoring and assessing what he learned Anderson \& Kathwohl (2001). Desoete (2001) states that metacognitive skills refers to the skills of planning (planning skills), skills monitroring (monitoring skills), skills evaluation (evaluation skills) and skills of prediction (prediction skills) (Wall K, 2009).

Van Hount-Woltes (2006) agree that contains metacognitive skills activities in the orientation phase, adjustment of monitoring, planning, evaluation and reflection. Previous research also represents a lot of this category is concluded by Veenman et al (1977), there are three important stages during the process of metacognitive control: planning, monitoring and evaluation. In line with previous research, Hong (1999) refers to metacognitive activity consists of actions such as planning or goal setting and monitoring solutions. Minnaert and Janssen (1999) in their study using a questionnaire with questions metacognitive refers to activities on the stage of goal setting, orientation, planning, monitoring, testing, diagnosis, evaluation and reflection. Malpass et al (1999) defines metacognition as consisting of consistency awareness, planning, evaluation, and monitoring.

\section{Methodology Research}

This research has been conducted in Senior High School 5 Mataram at the first Class amounted 177 students. Design of research can be seen in table 1 below:

Table 1: Draft $2 \times 2$ factorial analysis

\begin{tabular}{|c|c|c|c|}
\hline & \multicolumn{2}{|c|}{ Learning Model (A) } \\
\hline & & TAI $\left(A_{1}\right)$ & Conventional $\left(\mathrm{A}_{2}\right)$ \\
\hline \multirow{2}{*}{$\begin{array}{l}\text { Metacognitive skills } \\
\text { (B) }\end{array}$} & High $\left(B_{1}\right)$ & $\mathrm{A}_{1} \mathrm{~B}_{1}$ & $\mathrm{~A}_{2} \mathrm{~B}_{1}$ \\
\hline & Low $\left(B_{2}\right)$ & $\mathrm{A}_{1} \mathrm{~B}_{2}$ & $A_{2} B_{2}$ \\
\hline
\end{tabular}

In each class there is a group that has a high and low metacognitive skills. Thus there are 4 groups: (1) $A_{1} B_{1}$ that learners are given cooperative learning model of TAI for high metacognitive skills, (2) $A_{1} B_{2}$ that learners are given cooperative learning model of TAI for low metacognitive skills, (3) $A_{2} B_{1}$ namely learners are given the conventional learning model for high metacognitive skills, and (4) $A_{2} B_{2}$ that learners are given the conventional learning model for low metacognitive skills.

To know the results of learning, learners are given the test in the form of an essay test based metacognitive skills. As for knowing whether the learners with different levels of metacognitive skills will metacognitive skills assessed using a questionnaire that aims to divide the group into two groups, 
namely metacognitive skills metacognitive skills of high and low metacognitive skills (Moises and Masamichi, 2006). Hypothesis testing is done by using Anava two way test. For ease of calculation, the anava test will be calculated by SPSS 20. Decision of the test: (1) If Fcount $\leq$ F table, with a significance level of $0.05 \%$ then $\mathrm{Ho}$ is accepted or $\mathrm{Ha}$ is rejected that means insignificant. (2) If Fcount $\geq \mathrm{F}$ table, with a significance level of $0.05 \%$, Ho is rejected or Ha is accepted. To determine the mean difference between groups of cells at Anava carried further by using t-test two parties.

\section{Findings And Discussion}

The average value of the cognitive learning based cognitive achievement test learners can be seen in table 2 below:

Table 2: Outcomes learning

\begin{tabular}{lllll}
\hline Model & $\begin{array}{l}\text { High-Low } \\
\text { Metacognitif skill }\end{array}$ & Mean & Std. Deviation & N \\
& High & 92,8667 & 4,35671 & 15 \\
\cline { 2 - 5 } TAI & Low & 82,5714 & 6,73355 & 14 \\
\cline { 2 - 5 } & Total & 87,8966 & 7,61270 & 29 \\
\hline \multirow{2}{*}{ Conventional } & High & 92,0000 & 5,83095 & 14 \\
\cline { 2 - 5 } & Low & 80,5294 & 4,43167 & 17 \\
\hline \multirow{2}{*}{ Total } & Total & 85,7097 & 7,67330 & 31 \\
& High & 92,4483 & 5,04683 & 29 \\
\hline & Low & 81,4516 & 5,58473 & 31 \\
\hline & Total & 86,7667 & 7,65875 & 60 \\
\hline
\end{tabular}

After the treatment given to each group in this study show and average value of cognitive learning achievement as seen in Figure 1 below:

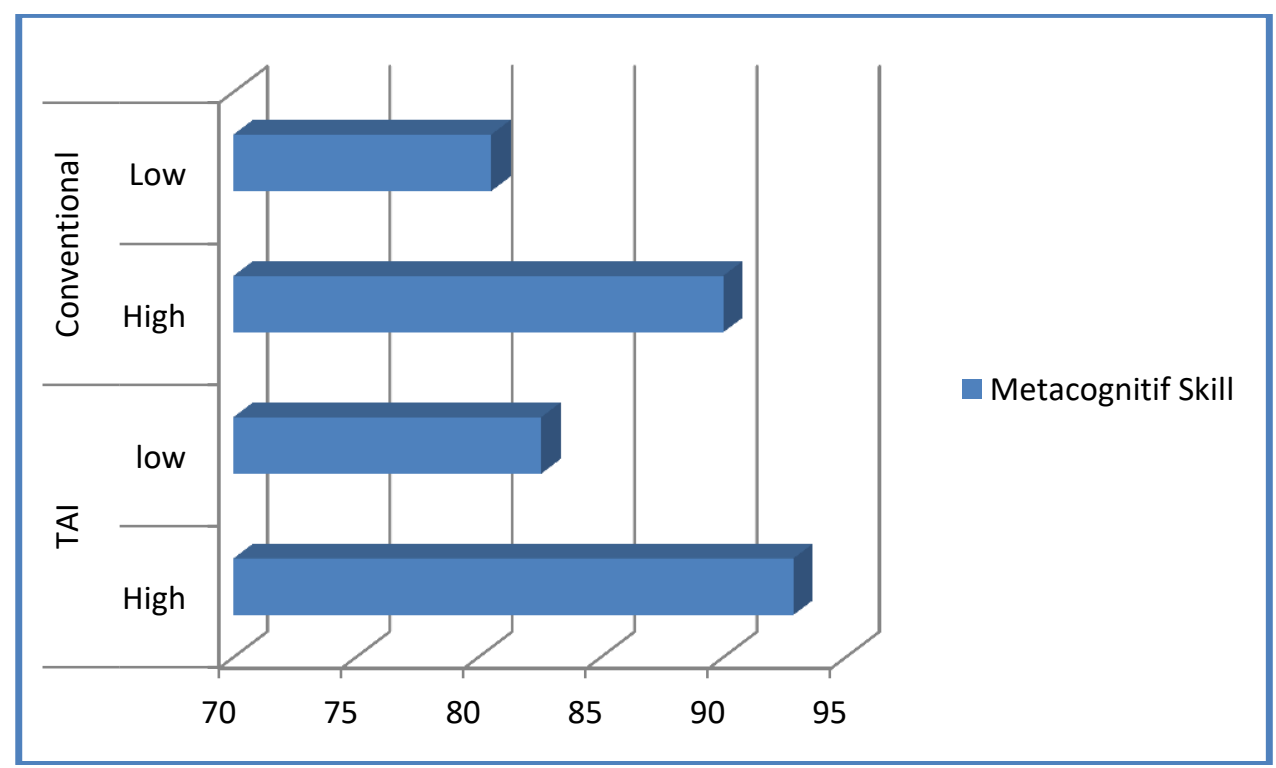

Figure 1: Chart of average outcomes student 
Based on the description of the table the average value of cognitive learning results above show that the average value of cognitive learning outcomes of students who get to use the model of cooperative learning TAI type of 87.89 while for groups of learners who use conventional learning models for 85.70 . It shows that the average value for the group of learners who use the cooperative model of TAI is higher than the group of learners who use conventional models. Another thing that is seen in the histogram above are students who have a high metacognitive skills, on average higher cognitive learning outcomes both in learning TAI type cooperative model and the conventional model.

Table 3: The results of hypothesis testing analysis

\begin{tabular}{|c|c|c|c|c|c|}
\hline \multicolumn{6}{|c|}{$\begin{array}{l}\text { Tests of Between-Subjects Effects } \\
\text { Dependent Variable: Learning Outcomes }\end{array}$} \\
\hline Source & $\begin{array}{l}\text { Type III : } \\
\text { Squares }\end{array}$ & & Mean Square & $\begin{array}{l}\text { F } \\
(\text { Ftable }=4,00)\end{array}$ & $\begin{array}{l}\text { Sig. } \\
(\alpha=0,05)\end{array}$ \\
\hline Model & 31,528 & 1 & 31,528 & 1,096 &, 300 \\
\hline Metacognitif Skill & 1765,440 & 1 & 1765,440 & 61,353 & ,000 \\
\hline $\begin{array}{l}\text { Model* } \\
\text { Metacognitif Skill }\end{array}$ & 5,148 & 1 & 5,148 &, 179 & ,674 \\
\hline
\end{tabular}

Table 4. Summary of Test Results Continue Anava

\begin{tabular}{|c|c|c|c|c|c|c|c|}
\hline \multirow[b]{2}{*}{ Source } & \multicolumn{7}{|c|}{ t-test for Equality of Means } \\
\hline & $\begin{array}{l}\text { t (two- } \\
\text { tails) }\end{array}$ & & Sig. & $\begin{array}{l}\text { Mean } \\
\text { Difference }\end{array}$ & $\begin{array}{l}\text { Std. } \\
\text { Differenc }\end{array}$ & $\begin{array}{l}\text { Errorttable } \\
\text { e }\end{array}$ & Decision \\
\hline $\mathrm{M} 1><\mathrm{M} 2$ & 456 & 27 & 652 & 86667 & 1,90258 & 2,160 & Ho is accepted \\
\hline $\mathrm{M} 1><\mathrm{M} 3$ & 4,923 & 27 & 000 & 10,29524 & 2,09137 & 2,160 & Ho is rejected \\
\hline $\mathrm{M} 3><\mathrm{M} 4$ & 1,014 & 29 & 319 & 2,04202 & 2,01464 & 2,160 & Ho is accepted \\
\hline $\mathrm{M} 2><\mathrm{M} 4$ & 5,467 & 26 & 000 & 10,35714 & 1,89449 & 2,160 & Ho is rejected \\
\hline
\end{tabular}

\section{Discussion}

Based on the above research data can be explained that the use of the learning model of the cognitive learning outcomes indicate Fratio value $=1.096$ with a number of significant value $=0.300$. Significant figures are greater than the significant level of 0.05 and Fratio smaller than $\mathrm{F}$ table $=4$, then Ho is accepted and Ha rejected, which means that there is no difference in cognitive achievement among students who use the model of cooperative learning TAI type with conventional learning model in physics dynamic electrical material. However, although both learning models do not provide a significant difference in learning outcomes, but give effect to the improvement of student learning outcomes. The difference of higher learning outcomes for learners who use cooperative learning model TAI compared learners who use conventional models show that cooperative learning model of TAI create learning situations that can support the improvement of learning outcomes and skills of learners.

Cooperative learning model of TAI be set so that learners are able to help a fellow member of the group when experiencing difficulties. TAI cooperative learning model will allow students to be a source of learning for others. This concept was developed from Vigotsky theory which teaches that every student learn the concepts best when the concept was in the zone closest to them. Nearest development zone when they engage in tasks that can not be solved alone, but can be solved when aided by his peers (Slavin, 2008). 
Johson (2003), which suggests a variety of findings on the use of models pembelajan cooperative TAI among others: (1) Allow the students learn about the skills, (2) Enable students to make adjustments, (3) Increase trust with others, (4) Improve the intrinsic motivation to learn, (5) improve positive thinking towards learning and experiential learning.

The results of this study indicate that the learning outcomes using conventional models in senior high school students of the first class in physics subject of dynamic electric is almost equivalent to the cooperative model in particular cooperative models TAI. With the collaboration of the expository method, demonstrations and lectures (conventional) can significantly improve learning outcomes. Expository method is one of effective teaching method, because in the process of implementation is more active learners. Pupils learn to be more active, because the portion of the teacher's lectures less. More teachers provide opportunities for students to work on the problems themselves work or ask a friend. Some research (in the US) stated expository method is the most effective way of teaching and efficient (Wieman et al., 2005).

Based on the learning process in the classroom activities with a demonstration method seems that every step of learning from things that demonstrated it can be seen easily by the pupil and the correct procedure learners more easily understand the subject matter. This is in line with that expressed by Minnaert et.al., (1999) that by demonstrating an action, process or procedure, method of demonstration has the following advantages: (1) teaching becomes clearer and more concrete, thus avoiding verbal (understanding words or sentence); (2) learners more easily understand what is learned; (3) the process of teaching a more attractive; (4) students are stimulated to actively observe, adjust between theory and reality, and try to do it yourself.

Other results are revealed in this study is the metacognitive skills of learners provide significant difference learning outcomes, both on learners who use cooperative learning model of TAI and the learners who use conventional learning model. This was revealed by the results of the calculation of the analysis of variance (ANAVA) using SPSS 20 on a significant level of $5 \%$ with a degree of freedom is obtained Fcount 1:56 at 61.35 while Ftable of 4, which means the value of Fcount> F table. Likewise with acount was 0.000 while $\alpha$ table of 0.05 , which means that $\alpha$ count $>\alpha$ table. It shows that the alternative hypothesis is accepted that the difference in learning outcomes between students who have a high metacognitive skills and learners who have low metacognitive skills. In addition it is also seen that the descriptive analysis of the average value of learning outcomes of students who have a high metacognitive skills better than the study of students who have low metacognitive ketarampilan.

In Hong (1999) researched that students who have a high metacognitive skills will certainly have a better understanding of the concept as well. Metacognitive skills that can assist learners in mastering the concepts in depth because the learners are able to control the learning process. Moises and Masamichi (2006) stated that many academic learning outcomes associated with memory skills and metacognitive skills where metacognition high academic learning outcomes will be better when compared with students who have low levels of cognition. So the higher the metacognitive skills of students, the higher the learning outcomes of students. Vice versa, the lower the metacognitive skills of learners, the lower the learning outcomes of students.

The other thing that was revealed in the study of the interaction between learning using learning model with metacognitive skills, based on the analysis of variance with the degree of freedom of 1:56 and $5 \%$ significance level obtained $\mathrm{F}$ value of 0.17 while the $\mathrm{F}$ table for 4 , which means Fcount $<$ Ftable and significant values $(\alpha)$ of 0.647 while $\alpha$ table $=0.05$ which means $\alpha$ count $>\alpha$ table. It shows that the initial hypothesis is accepted that there is no interaction between the uses of metacognitive skills learning model with the learning outcomes. However, it does not mean that the model of learning and metacognitive skills did not affect the learning outcomes of students. Descriptive statistically average student learning outcomes showed that the interaction using TAI type learning model with high metacognitive skills (92.86) is almost the same compared to the use of conventional learning model with high metacognitive skills (92.00). This means that the students who have high 
metacognitive skills in the learning process can use cooperative learning model of TAI and the conventional model. As for interaction use TAI type learning model with low metacognitive skills of the average student learning outcomes at 82.5 higher than the interaksu use conventional learning model with high metacognitive skills where the average student learning outcomes at 80.50 . This means that for students who have a better low metacognitive skills using cooperative learning model TAI compared with conventional models.

Anderson \& Kathwohl (2001) states that the metacognitive awareness of what is known and what is unknown. If consciousness is manifested (high metacognitive skills) then one can start thinking in designing, monitoring and assessing what is learned. Metacognitive skills associated with learning outcomes achieved by learners on a subject matter. Learning outcomes is essentially a change in behavior as a result of the learning process. A learning process is said to be effective if the learning outcomes achieved learners can achieve a predetermined indicators. So it can be said that there is a positive relationship between learning achievement with metacognition.

Based on the results of further testing using t-test, in this study revealed that there were no differences in cognitive learning outcomes of students between the use of cooperative learning model of TAI and the use of conventional models both on learners who have high or low metacognitive skills. It is meant for high school students in first sciens class can be used TAI type of cooperative models and conventional models (expository method and demonstration) to improve learning outcomes.

\section{Conclusions}

Based on the analysis of research data, it can be concluded as follows:

1) There were no differences between the students' cognitive learning outcomes of learning using cooperative learning model of TAI and conventional models in dynamic electrical material physics. However, learning to use cooperative learning TAI give lightly better results than learning to use the conventional model.

2) There are differences in cognitive learning outcomes between students who have a high metacognitive skills and low metacognitive skills in learning physics dynamic electrical material. Students who have a high metacognitive skill have the cognitive learning outcomes better than students who have low metacognitive skills.

3) There is no interaction between the use of learning models (TAI type of cooperative and Conventional) with metacognitive skills (high and low) on cognitive learning outcomes of students in learning physics dynamic electrical material.

\section{REFERENCES}

Anderson, O.W. \& Krathwohl, D.R., (2001), Taxonomy for Learning, Teaching, and Assessing (A Revision of Bloom's Taxonomy of Educational Objectives), Addision Wesley Longman, Inc, New York.

Desoete, A., (2001), Metacognition in Children with Mathematics Learning Disabilities, UniversiteitGent, Wetenschappen.

Hong, E. 1999, Studying the Mind of the Gifted, In Michell, H.L., Annemieke, E.J., Metacognitive Skills of The Gifted From A Cross-Cultural Perspective, Netherlands, 2008, pp. 3-43.

Hount-Wolters, Van, B.H.A.M. (2006), Assesing Active Self Directed Learning, In Michell, H.L., Annemieke, E.J. Metacognitive Skills of The Gifted From A Cross-Cultural Perspective, Netherlands, 2008, pp. 3-43. 
Mallpas J.R., O’Neil, J.H.F. 1999, Self Regulation, Goal Orientation, Self Efficacy and High Stakes Math Achievement. In Michell, H.L., Annemieke, E.J. Metacognitive Skills of The Gifted From A Cross-Cultural Perspective, Netherlands, 2008, pp. 3-43

Minnaert, A., Janssen, P.J. 1999, The additive effect of Regulatory Activities on Top of Intellegence in Relation to Academic Performance in Higher Education, In Michell, H.L., Annemieke, E.J. Metacognitive Skills of The Gifted From A Cross-Cultural Perspective, Netherlands, 2008, pp. 343

Moises, K.C.F., Masamichi, Y. 2006, Social Influences on Metamemory Judgment, Hiroshima University, Vol.6, 39-46.

Patel VL, Groen GJ, Norman GR. Effects of conventional and problem-based medical curricula on problem solving, Acad Med 1991, pp.66:380

Slavin, R.E. 2008. Cooperative Learning (Theory, Reset, And Practice). Bandung: Nusa Media.

Wall, K. and Higgins, S. 2007 Learning to Learn in Schools: How are pupils thinking differently about their learning? Paper presented at the European Association for Research into Learning and Instruction (EARLI) Conference, Budapest, August 2007.

Wieman, C. \& Perkins, K. (2005), Transforming physics education, Physics Today, 58(11), pp.36-41. 